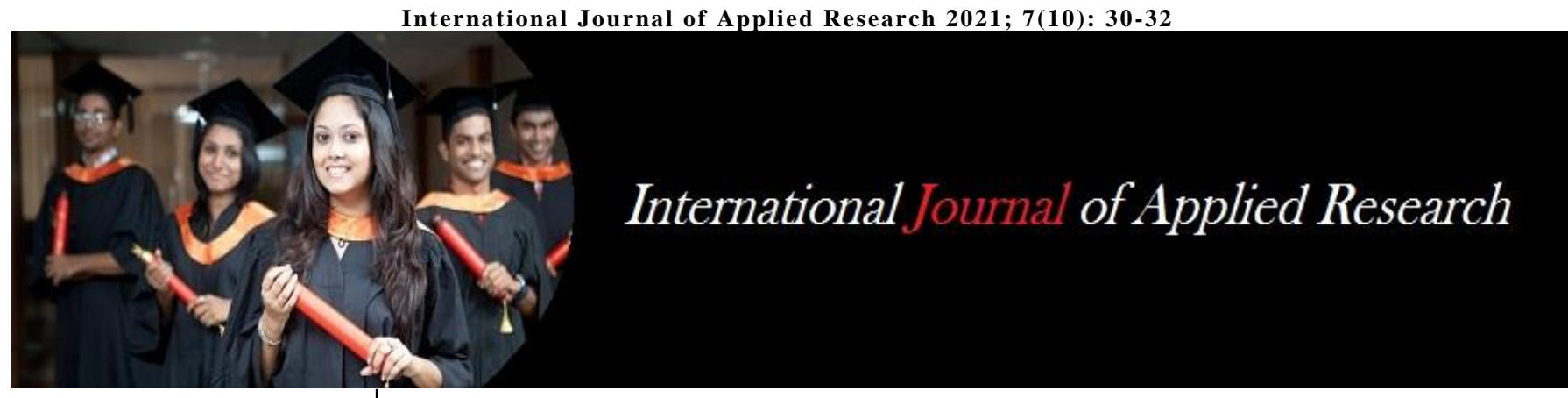

ISSN Print: 2394-7500 ISSN Online: 2394-5869 Impact Factor: 8.4 IJAR 2021; 7(10): 30-32 www.allresearchjournal.com

Received: 22-08-2021 Accepted: 24-09-2021

Sandeep Sharma Lecturer in Philosophy, Govt. Degree College Akhnoor, Jammu and Kashmir, India

\section{The problem of rebirth: Belief versus reality, an overview}

\section{Sandeep Sharma}

DOI: https://doi.org/10.22271/allresearch.2021.v7.i10a.9002

Abstract

Almost all religions of the worlds have this common belief in 'life after death'. Beliefs in life after death varied from religion to religion but there is a wider gap in the understanding of the concept in religions originated in the Asian continent as well as Abrahamic religions in the western world. Eastern originated religions logically defend this belief in the form of rebirth and Abrahamic religions too logically establish the concept of resurrection instead of rebirth. The point I like to raise in my paper is, is Rebirth a matter of belief or is there something logical behind it. If, it is a matter of belief than it is limited to believers only and if there is something logical behind this problem of rebirth than it is objectively applicable to all. If latter case is true, many of our religious beliefs seem contradictory. So, I limit my focus to these two questions, is rebirth a matter of belief? Does faith determine the reality?.

Keywords: death, rebirth, karma, Abrahamic, resurrection, religion

\section{Introduction}

There are number of philosophical theories regarding the human existence that covers various philosophical problems like birth, rebirth as well as freedom from the cycle of birth and death. Like other philosophical problems, 'Life after death' is equally a philosophical problem because many of our metaphysical beliefs like belief in eternal soul, law of karma etc. allow us to enquire about it. Beliefs in eternal soul and law of karma help philosopher and intellectual to defend life after death. The simple problem that I put light on is, is rebirth a matter of belief or is there any objective reality in it that is equally applicable to all individuals.

As there are number of religions in world, which is classified as eastern religions as well as Abrahamic religions. There are wide differences in their general beliefs and faiths like the concept of God, Soul, life, values and various ethical and moral principles that are followed by their followers. One belief that I like to focus on is, 'life after death'. As regards to the belief in life after death, Eastern religions propagate this view that after the death of physical body, eternal soul transmigrates into another body which is strictly regulated by the law of karma. It is the karmas that decide our life after death: rebirth, hell or heaven are the common option that human have and which is determined according to human actions during his stay on this earth planet in physical body. Life does not end with physical death, we have to reap whatever we sow in the form of desired actions, and each action determined by desire leave an impression and that impression become the cause of rebirth.

On the other hand, Abrahamic religions also have one of the popular beliefs in life after death, but it is different in many ways from the religions originated in the Indian subcontinent and they termed it as resurrection. Resurrection is different from rebirth. The prime objective of Resurrection is to bring human beings back into existence for final judgments after death into the court of God where they will be judged, based on their good or bad deeds, and accordingly rewarded.

Eastern religions irrespective of the different faith and beliefs hold this common belief i.e. 'belief in rebirth'. The popular eastern religion includes Hinduism, Buddhism, Jainism and Sikhism. The common belief that Hinduism, Jainism and Sikhism share is belief in the existence of soul, the conception of rebirth is accepted by most eastern religion is actually 
has its base in the eternal soul and it is soul along with the karmic matters that transmigrates from one form to another which is termed as rebirth. So it can be said that it is the conception of eternal soul that make eastern thinkers to believe that action done with attachment produce result which caused subtle body and subtle body always found along with the soul. Until subtle body accompanying the soul, the process of rebirth is not going to an end. It means that belief in the existence of soul and the concept of rebirth is closely related. Any doubt in the existence of soul leads to doubt the very conception of rebirth. Everything ends with physical death but soul survives and this is the reason eastern religion supports the belief in rebirth. The belief in soul is common to various eastern religions like Hinduism, Jainism, and Sikhism etc. but this belief in eternal soul is equally rejected by eastern religions like Buddhism.

Buddhism as a religion is generally termed as pragmatic religions, because many of irrational beliefs as generally accepted by almost all religions of the world are rejected by Buddhism. Buddhist theory of momentariness not allowed believing in anything metaphysical which is eternal. So in Buddhism there is no scope of accepting an eternal entity like soul as we generally found in the eastern religions. Even agnostic view regarding the eternal soul doesn't stop Buddha to believe in rebirth. It is generally accepted that in original Buddhism there is no metaphysics but acceptance of this belief in rebirth put question mark on this claim because Gautama Buddha the founder of Buddhism, himself told his previous birth life tales which is recorded in Jatkas. So in Buddhism, rebirth is not merely a belief but it is something practical. The secret to rebirth is unfolded in pratiyasamutapada (theory of conditional existence) which is contained in second noble truth. In the chain of twelve steps, conditional existence begin with ignorance which caused impressions, impressions are the seeds which start growing in the form of consciousness, so it is consciousness that determines the rebirth. If there is no consciousness, than there is no rebirth. Therefore, in Buddhism instead of eternal soul, it is consciousness that is accepted as the cause of rebirth. Everything physical is momentary and liable to decay but consciousness or impressions is psychological in nature and it does not end with the physical body. It is consciousness that transforms itself into new life and nature of new life i.e. rebirth is totally determined by the impressions or consciousness of previous birth and Buddhist believes that to free from the cycle of birth and death, all we need to do is to break the chain as mentioned in second noble truth. Ignorance is treated as main points of that chain and it caused impressions. Once ignorance is destroyed, there is no impression and there is no rebirth. This is the state of freedom which is termed as Nirvana in Buddhism.

On the other hand, another aspect of 'life after death' is the conception of resurrection accepted by all the Semitic religions includes Christianity, Judaism, Zoroastrianism as well as Islam. In Semitic religions common belief is after the physical death, on the day of final judgement, dead resurrected and final allotment to heaven or hell is done by God on the basis of good and bad actions done on earth by each individual. As the 'Day of Judgement' comes in the near future, Judaism does not seems to be clear about the fate of the dead in intermediary period, i.e. during the period between individual death and the final day of judgement, resurrection of the dead and the allotment of heaven and hell. In Islam, it is believed that after the death soul live in
Albazrzahk during the intermediary period. Christianity on the other hand hold the view that good actions leads to heaven and bad actions leads to hell but on the final day of judgment, all resurrected to life again and are brought before God and are finally allotted heaven or hell eternally. Like Islam, Zoroastrianism gives a description of the passage also that leads to either heaven or hell. Before reaching heaven or hell, the soul has to cross a bridge called Al-sirat. For those who indulge in sinful activities the bridge seems to be as thin as a sword edge and they falls down, below in the abyss of suffering-the hell, but for the virtuous ones the bridge seems to be quite wide such that they crosses over it easily and goes to paradise. If we closely analyses this belief i.e. life after death, what we find in the Semitic religions is that no way they support the concept of rebirth as we found in almost all the Asian religions.

I like to propose here a thought experiment to check the scientific and philosophical validity of this famous religious beliefs, 'belief in rebirth'. The standard belief is that rebirth follows after death but this belief is not accepted by many religions of the world. The religions originated in Asian continent held this belief that life doesn't end merely with physical death, life continues in the form of rebirth until soul get liberated from the bondage of psychological body. On the other hand, religions has its origin in other parts of the world don't accepted this belief in life after death in the form of rebirth; rather resurrection is accepted as a substitute to life after death. So in sematic religions there is no possibility of returning into new life again after physical death. So, let suppose two individual belonging to two different religious beliefs are very close friend, one belong to Buddhism and another belong to Islam, travelling in a motor bike and an accident took place and both got killed. As per their religious beliefs individual belong to the Buddhist beliefs has the higher chance to reborn again in human form but on the other hand individual belong to the Islamic beliefs not going to reborn instead he wait for the 'day of judgement' to happen when on the basis of his karma, allotment of heaven or hell will take place. If this is the case, it is beliefs that determine the reality but is this logical? No way, either rebirth is a reality or it's a myth. In universal perspective reality is objective in nature but as per above thought experiments, if we look at the phenomenal aspect of existence, even reality seems contradictory. If rebirth is a reality or a myth it must be applicable on all humans irrespective of their faiths and beliefs. But this is not the case; so it is a philosophical problem to reflect on.

The close examination of these beliefs, the acceptance of rebirth by eastern religions and rejection by Abrahamic religions bring elements of skepticism, and doubt in the objective validity of this philosophical as well as religious concept. Acceptance and denial by few which is clearly determined by their respective faith does not create the logical ground for this belief. So, it is debatable whether rebirth is a matter of belief or it is an important aspect of reality.

\section{Conclusion}

If the problem of rebirth is to be examined from an impartial point of view, it is necessary first of all to find a way of bypassing such unempirical barriers as religious bias. Neither there is strong objective evidence nor specific research methods that can discover the mystery of life after death in the form of rebirth. However, not everything can be 
known by the humans with their current mind and intelligence that are far limited to perceive such paranormal phenomenon. Thus there is nothing much to conclude. However, one thing is very clear. Human mind's greatest weakness is to reduce concepts that fit into its belief and then believe that this is the only truth. It also becomes necessary for the intellectual to review the causes of the origin of different religious beliefs as well as practices. Such diverse practices lead to the origin of different religions. Each religion and each spiritual teacher differs in their view of life after death. However, there cannot be many truths. So it appears that the knowledge of noumenal aspect is beyond the limits of human understanding.

\section{References}

1. Tewari KN. Comparative Religion. Second Reprint edition, Motilal Banarsidass Publishers, 1997.

2. Masih Y. A Comparative Study of Religions, 7th edition Motilal Banarsidass, 2017.

3. Sharpe, Eric J. Comparative Religion: A History, Duckworth, 1975.

4. Hick, John. Philosophy of Religion. 4th edition, Pearson Education India, 2015.

5. Tewari KN. Classical Indian Ethical Thought. 2nd edition, Motilal Banarsidass Publishers, 2017. 